\title{
Penentuan Daya Tampung Kali Surabaya Segmen Tambangan Cangkir - Bendungan Gunungsari Dengan Pemodelan QUAL2Kw
}

\author{
Nur Aini Febriyana, dan Ali Masduqi \\ Jurusan Teknik Lingkungan, Fakultas Teknik Sipil dan Perencanaan, Institut Teknologi Sepuluh \\ Nopember (ITS) \\ Jl. Arief Rahman Hakim, Surabaya 60111 Indonesia \\ e-mail: masduqi@its.ac.id
}

\begin{abstract}
Abstrak-Kali Surabaya merupakan salah satu sungai yang dijadikan sumber air baku oleh PDAM Kota Surabaya. Peningkatan pembuangan limbah industri maupun limbah domestik dapat menurunkan kualitas air Kali Surabaya. Oleh karena itu diperlukan upaya pengelolaan kualitas air Kali Surabaya, terutama penentuan daya tampung dan beban pencemaran air Kali Surabaya dengan Metode QUAL2Kw. Metode QUAL2Kw diawali dengan penentuan 5 segmen. Selanjutnya dilakukan analisis data hidrolik, kualitas air, dan sumber pencemar, penentuan skenario yang digunakan, running program QUAL2Kw dan perhitungan daya tampung beban pencemaran. Parameter kualitas air sungai yang digunakan meliputi: temperatur, pH, DO, BOD, COD, TSS, Fosfat, Nitrat, dan Amonium. Aplikasi metode QUAL2Kw dalam mengevaluasi Kali Surabaya dengan simulasi 6 skenario menghasilkan perhitungan daya tampung beban pencemaran maksimum untuk parameter Nitrat sebesar 21414,730 kg/hari, parameter Amonium sebesar 468,073 kg/hari. Beban pencemaran air Kali Surabaya yang harus diturunkan sebesar $65518,647 \mathrm{~kg} / \mathrm{hari}$ untuk parameter TSS, BOD sebesar $6896,759 \mathrm{~kg} / \mathrm{hari}$, dan Fosfat sebesar $357,707 \mathrm{~kg} / \mathrm{hari}$.
\end{abstract}

Kata Kunci-Beban pencemaran, Daya tampung, Kualitas air, Pemodelan QUAL2Kw.

\section{PENDAHULUAN}

$\mathrm{K}$ ALI Surabaya merupakan salah satu sungai yang dijadikan sumber air baku oleh PDAM Kota Surabaya. Untuk itu, pemantauan kualitas air perlu dilakukan untuk menjaga Kali Surabaya tetap memenuhi baku mutu. Beberapa penelitian sebelumnya telah dilakukan beberapa kajian mengenai pencemaran air dan pengendalian beban pencemaran air yang terjadi di Kali Surabaya. Tingginya tingkat pencemaran tidak lepas dari lemahnya mekanisme pengendalian pencemaran. Pencemaran yang masuk pada Kali Surabaya meliputi industri, domestik dan pertanian. Limbah domestik sebagai penyumbang pencemar terbesar pada air Kali Surabaya.

Menurut [1] menyatakan domestik menyumbang 65 persen pencemaran, daripada industri yang hanya 30 persen, sisanya limbah pertanian. Industri banyak disumbang oleh industri rumahan dari kawasan Mlirip Mojokero hingga Karangpilang Surabaya yang belum memiliki instalasi pengolahan air limbah. Penyebab pencemaran dari sumber komersial antara lain berasal dari limbah rumah makan dan hotel $(17,8 \%)$, industri manufactur (20\%), dan kegiatan lainnya [2].
Berdasarkan [3] harus dilakukan upaya pengelolaan air limbah sebelum dibuang ke badan air Kali Surabaya. Pengendalian pencemaran air di Kali Surabaya telah dilakukan seperti adanya titik pantau. Titik pantau pada Kali Surabaya sebagai salah satu upaya agar pencemaran air tidak melampaui baku mutu air Kelas II menurut [4]. Namun hal itu masih kurang efektif jika hanya dari hanya dari satu pihak untuk melakukan pengendalian pencemaran. Sehingga, harus diketahui terlebih dahulu sumber pencemar dan daya tampung yang ada di Kali Surabaya menggunakan pemodelan QUAL2Kw.

Perhitungan daya tampung beban pencemaran sungai merupakan proses yang rumit karena air sungai mengalir secara kontinyu dan kualitas air sungai berubah-ubah dari hulu ke hilir. Semakin rapat antara jarak titik sampling, maka akan semakin dapat menggambarkan kondisi kualitas air yang sebenarnya. Tetapi hal ini akan berakibat pada mahalnya biaya observasi. Perhitungan daya tampung beban pencemaran sungai yang dilakukan menggunakan metode pemodelan dapat meminimalisir biaya observasi [5].

Model QUAL2Kw menggunakan bahasa pemrograman Visual Basic for Application (VBA) dapat dijalankan dengan program Microsoft Excel. Model ini mampu mensimulasi beberapa parameter antara lain suhu, $\mathrm{pH}$, Sediment Oxygen Demand (SOD), Carbonaous Biochemical Oxygen Demand (CBOD), Dissolved Oxygen (DO), Nitrogen Organik, Ammonia, Nitrit, Nitrat, Fosfor Organik, Fosfor Anorganik, Fitoplankton, Bakteri Pathogen, Alkalinitas Total Anorganik Karbon [6].

\section{METODOLOGI PENELITIAN}

\section{A. Pengumpulan Data dan Segmentasi}

Data sekunder yang dikumpulkan meliputi peta, kondisi hidrolis sungai, kualitas air sungai, kualitas air point source, jumlah penduduk Kota Surabaya dan kondisi meteorologi. Data primer yang diambil meliputi kualitas air sungai dan kondisi hidrolik sungai. Segmen dalam penelitian ini berjumlah 4 segmen. Pembagian segmen ini didasarkan pada masukan dari anak sungai, adanya tempat untuk pengambilan sampel serta outlet sumber pencemar. Pembagian segmen pemodelan dapat dilihat pada Tabel 1. 
Tabel 1.

Pembagian Segmen

\begin{tabular}{|c|c|c|c|c|c|c|}
\hline \multirow[b]{2}{*}{ Nama Segmen } & \multirow[b]{2}{*}{ Kilometer } & \multirow{2}{*}{$\begin{array}{c}\text { Panjang } \\
(\mathrm{km})\end{array}$} & \multicolumn{2}{|c|}{ Elevasi } & \multicolumn{2}{|c|}{ Koordinat } \\
\hline & & & $\begin{array}{c}\mathrm{Hu} \\
\mathrm{lu}\end{array}$ & $\begin{array}{l}\mathrm{Hi} \\
\text { lir }\end{array}$ & Hulu & Hilir \\
\hline \multirow{3}{*}{$\begin{array}{l}\text { Tambangan } \\
\text { Cangkir- } \\
\text { Tambangan } \\
\text { Bambe }\end{array}$} & $13,0-$ & 3,60 & 13 & 12 & $7^{0} 21^{\prime} 57,76^{\prime \prime}$ & $7^{0} 21^{\prime} 57,76^{\prime \prime}$ \\
\hline & 9,40 & & & & LS & LS \\
\hline & & & & & $\begin{array}{c}112^{0} 37^{\prime} 58,5 \\
2^{\prime \prime B T}\end{array}$ & $\begin{array}{c}112^{0} 39^{\prime} 58,5 \\
\text { 2”BT }\end{array}$ \\
\hline $\begin{array}{l}\text { Tambangan } \\
\text { Bambe- }\end{array}$ & $\begin{array}{c}9,40- \\
5,65\end{array}$ & 3,75 & 12 & 11 & $\begin{array}{c}\text { 7021'57,76" } \\
\text { LS }\end{array}$ & $\begin{array}{c}7020^{\prime} 54,54 " \\
\text { LS }\end{array}$ \\
\hline $\begin{array}{l}\text { IPAM Karang } \\
\text { Pilang }\end{array}$ & & & & & $\begin{array}{l}112039^{\prime} 58 \\
52^{\prime \prime B T ~}\end{array}$ & $\begin{array}{c}112040 ' 52, \\
52 \text { "BT }\end{array}$ \\
\hline \multirow{2}{*}{$\begin{array}{l}\text { IPAM Karang } \\
\text { Pilang- } \\
\text { Jembatan } \\
\text { Sepanjang }\end{array}$} & $\begin{array}{c}5,65- \\
3,90\end{array}$ & 1,75 & 11 & 10 & $\begin{array}{c}7020^{\prime} 54,54 ” \\
\text { LS }\end{array}$ & $\begin{array}{c}7020{ }^{\prime} 56,00 " \\
\text { LS }\end{array}$ \\
\hline & & & & & $\begin{array}{l}112040 ’ 52 \\
52 ” B T\end{array}$ & $\begin{array}{c}112041^{\prime} 42, \\
60 \text { "BT }\end{array}$ \\
\hline \multirow{2}{*}{$\begin{array}{l}\text { Jembatan } \\
\text { Sepanjang- } \\
\text { Bendungan } \\
\text { Gunungsari }\end{array}$} & $\begin{array}{c}3,90- \\
0,00\end{array}$ & 3,90 & 10 & 9 & $\begin{array}{c}7020^{\prime} 56,00 ” \\
\text { LS }\end{array}$ & $\begin{array}{c}7018^{\prime} 29,13^{\prime \prime} \\
\text { LS }\end{array}$ \\
\hline & & & & & $\begin{array}{c}112041^{\prime} 42, \\
60 ” \mathrm{BT}\end{array}$ & $\begin{array}{c}112043^{\prime} 8,0 \\
\text { 0"BT }\end{array}$ \\
\hline
\end{tabular}

\section{B. Teknik Simulasi}

Simulasi dalam penelitian ini terbagi menjadi 6 skenario yang akan digunakan untuk mendapatkan hasil kualitas dan daya tampung yang sesuai dengan Kali Surabaya. Berdasarkan [4], Kali Surabaya kategorikan sebagai air kelas dua. Saat ini Kali Surabaya belum memenuhi baku mutu Kelas II sehingga dilakukan penentuan daya tampung dan berapa penurunan yang harus dilakukan agar memenuhi baku mutu kelas II. Skenario smulasi untuk pemodelan dapat dilihat pada Tabel 2.

Tabel 2.

Skenario Simulasi

\begin{tabular}{|c|c|c|c|c|}
\hline Skenario & $\begin{array}{c}\text { Kondisi Air di } \\
\text { Hulu } \\
\end{array}$ & $\begin{array}{c}\text { Data } \\
\text { Sungai }\end{array}$ & $\begin{array}{c}\text { Sumber } \\
\text { Pencemar }\end{array}$ & Kualitas Air \\
\hline 1 & Eksisting & Eksisting & Eksisting & Model \\
\hline 2 & Eksisting & Eksisting & $\begin{array}{l}\text { Tidak ada } \\
\text { sumber } \\
\text { pencemar }\end{array}$ & Model \\
\hline 3 & Eksisting & Eksisting & $\begin{array}{l}\text { Trial dan } \\
\text { Error }\end{array}$ & $\begin{array}{l}\text { Baku Mutu } \\
\text { kelas II }\end{array}$ \\
\hline 4 & $\begin{array}{l}\text { Memenuhi Baku } \\
\text { Mutu Kelas II }\end{array}$ & Eksisting & Eksisting & Model \\
\hline 5 & $\begin{array}{l}\text { Memenuhi Baku } \\
\text { Mutu Kelas II }\end{array}$ & Eksisting & $\begin{array}{l}\text { Tidak ada } \\
\text { sumber } \\
\text { pencemar }\end{array}$ & Model \\
\hline 6 & $\begin{array}{c}\text { Memenuhi Baku } \\
\text { Mutu Kelas II }\end{array}$ & Eksisting & $\begin{array}{l}\text { Trial dan } \\
\text { Error }\end{array}$ & $\begin{array}{c}\text { Baku Mutu } \\
\text { Kelas II } \\
\end{array}$ \\
\hline
\end{tabular}

\section{Analisis Data}

Perhitungan daya tampung beban pencemaran ini berfungsi untuk mengetahui kemampuan maksimum badan air dalam menampung beban pencemaran yang masuk ke dalamnya [8]. Perhitungan daya tampung berdasarkan simulasi. Penetapan daya tampung beban pencemaran parameter yang dihitung pada setiap segmen adalah TSS, BOD, Nitrat, Amonium, dan Fosfat, sehingga dapat diketahui kemampuan Kali Surabaya dalam menampung beban pencemar yang masuk pada tiap segmen. Perhitungan daya tampung diperoleh dari selisih beban pencemaran penuh dan tanpa beban pecemaran [7].
Setelah diketahui daya tampungnya, maka akan diperoleh pula beban pencemaran yang harus diturunkan karena mencemari Kali Surabaya (tidak sesuai baku mutu perairan).

\section{ANALISIS DATA DAN PEMBAHASAN}

\section{A. Pembentukan dan Kalibrasi Model}

Segmen (reach) sungai telah dibentuk, selanjutnya memasukkan data ke dalam program QUAL2Kw. Data yang dimasukkan meliputi identitas sungai, debit dan kualitas hulu, identitas reach, sumber perencanaan point sources dan nonpoint sources, koefisien model, data hidrolik berupa sungai debit dan kualitas air sepanjang sungai serta data pendukung lainnya, seperti data kecepatan angin dan suhu udara. Setelah data dimasukkan pada media input (Microsoft Excel 2003), program QUAL2Kw dijalankan dengan melakukan kilik pada [Run VBA]. Dalam beberapa detik program QUAL2Kw akan menyelesaikan perhitungannya dan menampilkan hasil model pada worksheet yang menampilkan grafik tiap parameter [7]. Berikut hasil kalibrasi model simulasi Oksigen Terlarut (DO) sesuai data input pada Gambar 1 dan Simulasi BOD pada Gambar 2.

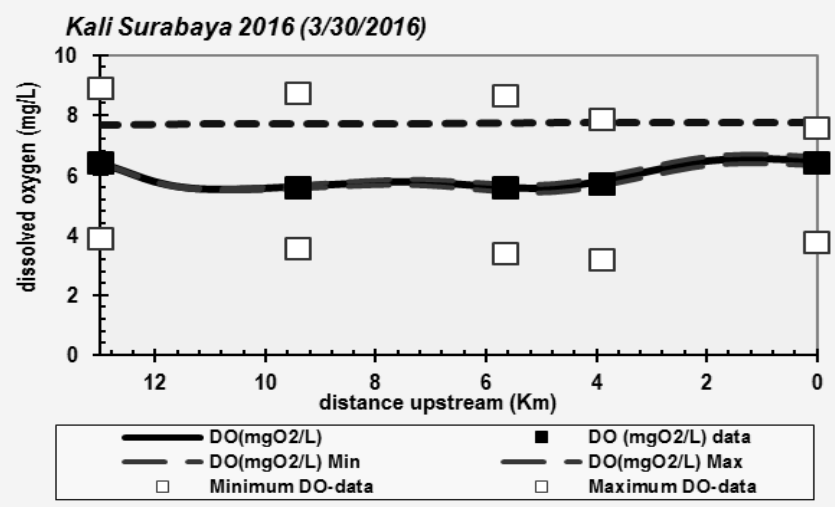

Gambar 1. Kalibrasi Model Simulasi BOD

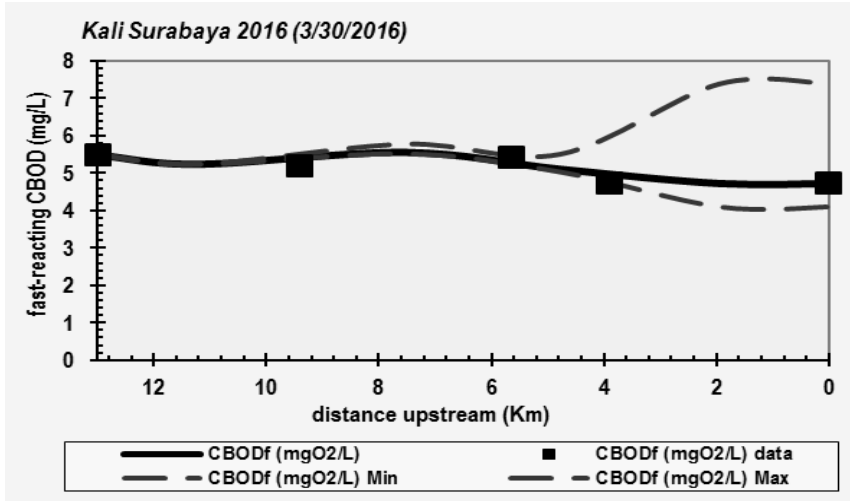

Gambar 2. Kalibrasi Model Simulasi BOD

Pemodelan parameter DO dan BOD pada Gambar 1 dan Gambar 2 menunjukkan bahwa model BOD tersebut sudah mendekati data. Hal ini ditunjukkan dengan tren garis (model) yang terlihat telah mengikuti tren titik kotak hitam (data). Grafik DO dan BOD berbanding terbalik. Terlihat pada kilometer 13.0 - 9,4 terjadi penurunan BOD lalu naik pada kilometer 9,4 - 5,65 karena adanya sumber pencemar yang 
masuk dan pada kilometer 5,65 - 0 BOD turun kembali dengan drastis pula. Penurunan BOD tersebut lalu dipengaruhi oleh oksigen terlarut (DO) untuk mendegradasi organik.

\section{B. Kondisi Kualitas Air Hulu Eksisring}

Model kualitas air Kali Surabaya yang telah didapatkan kemudian digunakan untuk melakukan simulasi skenario 2 dan skenario 3. Perhitungan daya tampung merupakan perhitungan selisih antara kondisi sungai dengan beban pencemar penuh (skenario 3) dan kondisi sungai dengan tanpa beban pencemar yang masuk (skenario 2). Perhitungan beban didapat dari hasil simulasi berupa debit dan konsentrasi pencemar pada worksheet Sources Summary. Hasil perhitungan beban pencemaran skenario 2 ditampilkan pada Tabel 3, sedangkan untuk skenario 3 ditampilkan pada Tabel 4 . Sementara itu hasil perhitungan daya tampung beban pencemaran ditampilkan pada Tabel 5 .

Tabel 3.

Beban Pencemaran Skenario 2

\begin{tabular}{ccccccc}
\hline \hline \multirow{2}{*}{ Kilometer } & TSS & BOD & Amonium & Nitrat & Fosfat & COD \\
\cline { 2 - 7 } & $\mathrm{kg} / \mathrm{h}$ ari & $\mathrm{kg} / \mathrm{h}$ ari & $\mathrm{kg} / \mathrm{h}$ ari & $\mathrm{kg} / \mathrm{hari}$ & $\mathrm{kg} / \mathrm{hari}$ & $\mathrm{kg} / \mathrm{hari}$ \\
\hline $13,00-9.40$ & 0 & 0 & 0 & 0 & 0 & 0 \\
$9,40-5,65$ & 3303.936 & 1492.992 & 91.2384 & 304.3872 & 175.2192 & 3718.656 \\
$5,65-3,90$ & 0 & 0 & 0 & 0 & 0 & 0 \\
$3,90-0,00$ & 0 & 0 & 0 & 0 & 0 & 0 \\
\hline \hline
\end{tabular}

Tabel 4.

Beban Pencemaran Skenario 3

\begin{tabular}{ccccccc}
\hline \hline Kilometer & TSS & BOD & Amonium & Nitrat & Fosfat & COD \\
\cline { 2 - 7 } & $\mathrm{kg} / \mathrm{hari}$ & $\mathrm{kg} / \mathrm{hari}$ & $\mathrm{kg} / \mathrm{hari}$ & $\mathrm{kg} / \mathrm{hari}$ & $\mathrm{kg} / \mathrm{hari}$ & $\mathrm{kg} / \mathrm{hari}$ \\
\hline $13,00-9.40$ & 0 & 0 & 468.0726 & 1.733184 & 0 & 61.27488 \\
$9,40-5,65$ & 0 & 0 & 405.2642 & 21719.1172 & 0 & 38924.1333 \\
$5,65-3,90$ & 0 & 0 & 120.668 & 50.74771823 & 0 & 2903.29654 \\
$3,90-0,00$ & 0 & 0 & 237.1941 & 202.4842473 & 0 & 9164.44545 \\
\hline \hline
\end{tabular}

Tabel 5.

Daya Tampung Beban Pencemaran (Eksisting)

\begin{tabular}{ccccccc}
\hline \hline \multirow{2}{*}{ Kilometer } & TSS & BOD & Amonium & Nitrat & Fosfat & COD \\
\cline { 2 - 7 } & $\mathrm{kg} / \mathrm{hari}$ & $\mathrm{kg} / \mathrm{h}$ ari & $\mathrm{kg} / \mathrm{hari}$ & $\mathrm{kg} / \mathrm{h} a r i$ & $\mathrm{~kg} / \mathrm{hari}$ & $\mathrm{kg} / \mathrm{hari}$ \\
\hline $13,00-9.40$ & 0.000 & 0.000 & 468.073 & 1.733 & 0.000 & 61.275 \\
$9,40-5,65$ & -3303.936 & -1492.992 & 314.026 & 21414.730 & -175.219 & 35205.477 \\
$5,65-3,90$ & 0.000 & 0.000 & 120.668 & 50.748 & 0.000 & 2903.297 \\
$3,90-0,00$ & 0.000 & 0.000 & 237.194 & 202.484 & 0.000 & 9164.445 \\
\hline \hline
\end{tabular}

\section{Kondisi Kualitas Air Hulu Memenuhi Baku Mutu Kelas II}

Model kualitas air Kali Surabaya ini hampir sama dengan skenario 1 sampai skenario 3 tetapi berbeda kondisi kualitas di hulu yang memenuhi baku mutu kelas II. Perhitungan daya tampung merupakan perhitungan selisih antara kondisi sungai dengan beban pencemar penuh (skenario 6) dan kondisi sungai dengan tanpa beban pencemar yang masuk (skenario 5). Perhitungan beban didapat dari hasil simulasi berupa debit dan konsentrasi pencemar pada worksheet Sources Summary. Hasil perhitungan beban pencemaran skenario 5 ditampilkan pada Tabel 6, sedangkan untuk skenario 6 ditampilkan pada Tabel 7. Sementara itu hasil perhitungan daya tampung beban pencemaran ditampilkan pada Tabel 8 .

Tabel 6.

Beban Pencemaran Skenario 5

\begin{tabular}{ccccccc}
\hline \hline \multirow{2}{*}{ Kilometer } & TSS & BOD & Amonium & Nitrat & Fosfat & COD \\
\cline { 2 - 7 } & $\mathrm{kg} / \mathrm{hari}$ & $\mathrm{kg} / \mathrm{hari}$ & $\mathrm{kg} / \mathrm{hari}$ & $\mathrm{kg} / \mathrm{hari}$ & $\mathrm{kg} / \mathrm{hari}$ & $\mathrm{kg} / \mathrm{hari}$ \\
\hline $13,00-9,40$ & 0 & 0 & 0 & 0 & 0 & 0 \\
$9,40-5,65$ & 3303.936 & 1492.992 & 91.2384 & 304.3872 & 175.2192 & 3718.656 \\
$5,65-3,90$ & 0 & 0 & 0 & 0 & 0 & 0 \\
$3,90-0,00$ & 0 & 0 & 0 & 0 & 0 & 0 \\
\hline \hline
\end{tabular}

Tabel 7.

Beban Pencemaran Skenario 6

\begin{tabular}{ccccccc}
\hline \hline \multirow{2}{*}{ Kilometer } & TSS & BOD & Amonium & Nitrat & Fosfat & COD \\
\cline { 2 - 7 } & $\mathrm{kg} / \mathrm{hari}$ & $\mathrm{kg} / \mathrm{hari}$ & $\mathrm{kg} / \mathrm{hari}$ & $\mathrm{kg} / \mathrm{hari}$ & $\mathrm{kg} / \mathrm{hari}$ & $\mathrm{kg} / \mathrm{hari}$ \\
\hline $13,00-9.40$ & 1699.488 & 0.000 & 468.073 & 1.733 & 0.170 & 61.275 \\
$9,40-5,65$ & 3853.514 & 0.000 & 405.264 & 21719.117 & 77.394 & 38924.133 \\
$5,65-3,90$ & 3618.531 & 0.000 & 120.668 & 50.748 & 10.262 & 2903.297 \\
$3,90-0,00$ & 19.382 & 0.000 & 237.194 & 202.484 & 15.087 & 9164.445 \\
\hline \hline
\end{tabular}

Tabel 8.

Daya Tampung Beban Pencemaran (Hulu mmenuhi Baku Mutu Kelas II)

\begin{tabular}{ccccccc} 
& TSS & BOD & Amonium & Nitrat & Fosfat & COD \\
\cline { 2 - 7 } & $\mathrm{kg} / \mathrm{h}$ ari & $\mathrm{kg} / \mathrm{hari}$ & $\mathrm{kg} / \mathrm{h}$ ari & $\mathrm{kg} / \mathrm{hari}$ & $\mathrm{kg} / \mathrm{h}$ ari & $\mathrm{kg} / \mathrm{hari}$ \\
\hline $13,00-9.40$ & 1699.488 & 0.000 & 468.073 & 1.733 & 0.000 & 61.275 \\
$9,40-5,65$ & 549.578 & -1492.992 & 314.026 & 21414.730 & -175.219 & 35205.477 \\
$5,65-3,90$ & 3618.531 & 0.000 & 120.668 & 50.748 & 0.000 & 2903.297 \\
$3,90-0,00$ & 19.382 & 0.000 & 237.194 & 202.484 & 0.000 & 9164.445 \\
\hline \hline
\end{tabular}

\section{Penurunan Beban Pencemaran}

Penurunan beban pencemaran merupakan jumlah beban pencemar yang harus diturunkan sehingga kualitas air Kali Surabaya dapat tetap memenuhi baku mutu badan air kelas II. Penurunan beban pencemaran didapatkan dengan menghitung selisih antara beban pencemaran eksisting pada skenario 1 pada Tabel 9 dengan daya tampung dari Kali Surabaya yang telah dihitung pada Tabel 5. Sehingga didapatkan penurunan beban pencemaran Kali Surabaya berdasarkan perhitungan pada Tabel 10.

Tabel 9.

Beban Pencemaran Skenario 1

\begin{tabular}{cccccc}
\hline \hline \multirow{2}{*}{ Kilometer } & TSS & BOD & Amonium & Nitrat & Fosfat \\
\cline { 2 - 6 } & $\mathrm{kg} / \mathrm{hari}$ & $\mathrm{kg} / \mathrm{hari}$ & $\mathrm{kg} / \mathrm{hari}$ & $\mathrm{kg} / \mathrm{hari}$ & $\mathrm{kg} / \mathrm{hari}$ \\
\hline $13,00-9,40$ & 1699.488 & 27.306 & 468.072 & 1.699 & 11.089 \\
$9,40-5,65$ & 41844.544 & 5403.767 & 92.202 & 497.063 & 182.488 \\
$5,65-3,90$ & 65518.647 & 14.371 & 120.634 & 48.020 & 10.217 \\
$3,90-0,00$ & 64685.778 & 44.156 & 237.024 & 193.824 & 14.945 \\
\hline \hline
\end{tabular}

Tabel 10.

Penurunan Beban Pencemaran 


\begin{tabular}{cccccc}
\hline \hline \multirow{2}{*}{ Kilometer } & TSS & BOD & Amonium & Nitrat & Fosfat \\
\cline { 2 - 6 } & $\mathrm{kg} / \mathrm{hari}$ & $\mathrm{kg} / \mathrm{hari}$ & $\mathrm{kg} / \mathrm{hari}$ & $\mathrm{kg} / \mathrm{hari}$ & $\mathrm{kg} / \mathrm{hari}$ \\
\hline $13,00-9.40$ & 1699.488 & 27.306 & 0.000 & 0.000 & 11.089 \\
$9,40-5,65$ & 45148.480 & 6896.759 & 0.000 & 0.000 & 357.707 \\
$5,65-3,90$ & 65518.647 & 14.371 & 0.000 & 0.000 & 10.217 \\
$3,90-0,00$ & 64685.778 & 44.156 & 0.000 & 0.000 & 14.945 \\
\hline \hline
\end{tabular}

Parameter beban pencemaran yang harus dhitung meliputi TSS, BOD, Nitrat, Fosfat, COD, dan Amonium, sedangkan untuk DO, $\mathrm{pH}$ dan suhu bukan merupakan pencemaran dan masih memenuhi baku mutu. Untuk nilai negatif pada nilai parameter menunjukkan beban pencemaran yang harus dituruankan. Hasil perhitungan menunjukkan kualitas air Kali Surabaya tercemar pada parameter BOD, TSS dan Fosfat. Beban pencemaran maksimum tiap segmen yang harus diturunkan pada Kali Surabaya sebesar $65518,647 \mathrm{~kg} / \mathrm{hari}$ untuk parameter TSS, BOD sebesar $6896,759 \mathrm{~kg} / \mathrm{hari}$, dan Fosfat sebesar $357,707 \mathrm{~kg} / \mathrm{hari}$.

\section{KESIMPULAN/RINGKASAN}

Aplikasi metode QUAL2Kw dalam mengevaluasi Kali Surabaya dengan simulasi 6 skenario menghasilkan daya tampung beban pencemaran maksimum untuk parameter Nitrat sebesar 21414,730 kg/hari, parameter Amonium sebesar $468,073 \mathrm{~kg} / \mathrm{hari}$. Beban pencemaran air Kali Surabaya yang harus diturunkan mencapai $65518,647 \mathrm{~kg} / \mathrm{hari}$ untuk parameter TSS, BOD sebesar 6896,759 kg/hari, dan Fosfat sebesar $357,707 \mathrm{~kg} / \mathrm{hari}$. Saran untuk penelitian lanjutan agar dilakukan kajian lebih lanjut dengan skenario yang lain, seperti variasi pada kondisi kualitas air dan debit sungai

\section{UCAPAN TERIMA KASIH}

Penulis mengucapkan terima kasih kepada Jurusan Teknik Lingkungan, FTSP-ITS sebagai fasilitator dalam menimba ilmu. Penulis juga mengucapakan terima kasih kepada BLH Provinsi Jawa Timur dan Perum Jasa Tirta yang telah memudahkan dalam pengambilan data. Penulis juga diperkenankan menyampaikan ucapan terima kasih seluruh pihak yang membantu penelitian ini.

\section{DAFTAR PUSTAKA}

[1] Faizal,A dan Desy A. (2015) Waspada Pencemaran Kali Surabaya Saat Musim Libur Lebaran. Kompas.

[2] Thornton, (2001) Pollutant in Urban Waste Water and Sewage Sludge. European Communities. Luxembourg.

[3] Peraturan Daerah Provinsi Jawa Timur (2008) Pengelolaan Kualitas Air dan Pengendalian Pencemaran Air di Provinsi Jawa Timur. Nomor 2 Tahun 2008. Surabaya.

[4] Peraturan Gubernur Jawa Timur (2010) Penetapan Kelas pada Air Sungai. Nomor 61 Tahun 2010. Surabaya.

[5] Fatmawati,R, Masrevaniah, Aniek, dan Solichin. Kajian Identifikasi Daya Tampung Beban Pencemaran Kali Ngrowo dengan Menggunakan Paket Program QUAL2Kw. Jurnal Teknik Pengairan. (Desember 2012) Vol.3. No.2:122-131.

[6] Pelletier,G dan S.Chapra (2006) QUAL2Kw User Manual (version 5.1): A Modelling Framework or Simulating River and Stream Water Quality. Washington: Environmental Assessment Program, Olympia.
[7] Rusnugroho, A dan Ali M. (2012) Penentuan Daya Tampung Beban Pencemaran Kali Madiun (Segmen Wilayah Kota Madiun) Menggunakan QUAL2Kw. Surabaya. Institut Teknologi Sepuluh Nopember.

[8] Keputusan Menteri Lingkungan Hidup (2003) Pedoman Penetapan Daya Tampung Beban Pencemaran Air Pada Sumber Air. Nomor 110 Tahun 2003. Jakarta 